\title{
Atypical presentations and rare metastatic sites of renal cell carcinoma: a review of case reports
}

\author{
Petros Sountoulides ${ }^{1 *}$, Linda Metaxa ${ }^{2}$ and Luca Cindolo ${ }^{3}$
}

\begin{abstract}
Renal cell carcinoma is a potentially lethal cancer with aggressive behavior and a propensity for metastatic spread. Due to the fact that the patterns of metastases from renal cell carcinomas are not clearly defined, there have been several reports of cases of renal cell carcinoma associated with rare metastatic sites and atypical presenting symptoms. The present review focuses on these atypical rare clinical presentations of renal cell carcinomas both at the time of diagnosis of the primary tumor but also in the years after radical nephrectomy.
\end{abstract}

\section{Introduction}

Renal cell carcinoma (RCC) is a lethal tumor that accounts for approximately $3 \%$ of all adult malignancies and is associated with approximately 13,000 deaths annually [1]. The introduction and widespread use of sophisticated imaging modalities has resulted in a significant increase in the incidental detection of kidney tumors. Nowadays more than $70 \%$ of all renal cancer cases are "screen detected" as incidental findings on imaging studies obtained for unrelated reasons [2]. Therefore the classical teaching that renal cancer presents with signs and symptoms such as hematuria, flank pain and palpable mass is more of the exception rather than the rule. This trend has also resulted in a significant shift in the staging of renal cancer since lesser cases initially present with advanced metastatic disease and more cases of renal tumors are confined to the kidney at the time of diagnosis.

Still, renal cancers have a strong tendency to metastasize following occasionally unpredictable patterns of spread. There have been several reports of late metastases from RCC even decades after potentially curative surgical excision of the primary tumor. There is evidence that distant metastatic disease will eventually develop in about one out of three patients with RCC and in these cases the disease is considered incurable. Even despite recent therapeutic advances in the management of metastatic renal cancer such as immunotherapy

\footnotetext{
* Correspondence: sountp@hotmail.com

'Department of Urology, General Hospital of Veria, Asomata Verias 59100, Veria, Greece

Full list of author information is available at the end of the article
}

and mTOR kinase inhibitors, long-term survival in patients with metastatic RCC is limited to months [3-5].

With regard to the histologic subtypes of RCC and their relationship to prognosis, the most common subtype, which is clear cell renal cancer, accounts for 70$80 \%$ of all RCCs. Chromophobe cell carcinoma accounts for only $3-5 \%$ of all RCCs and carries a better prognosis than clear cell RCC with a five-year survival rate between $92-94 \%[6,7]$. The pathologic stage of RCC at the time of presentation has been demonstrated to correlate most closely with survival [8].

\section{Metastatic pathway in RCC}

The development of metastatic disease is a sequential process where cancer cells depart from the primary tumor via the blood supply or lymphatic chain and deposit at proximal or distant sites. This metastatic pathway is not always predictable and certainly not for renal cancer, which is notorious for its complex lymphatic drainage. However there is a predilection for certain sites, meaning that these sites are usually the first occupied by cancer cells [9]. Moreover, there has been evidence in support of an early dissemination model, where metastasis occurs early in the lifecycle of cancer cells.

In an experimental study, engineered untransformed mouse mammary cells were found to express inducible oncogenes transgenes that were able to bypass the primary site and show up at secondary metastatic sites [10]. In another animal study, Kaplan et al. also showed that cancer cells in mice models might have instructed bone marrow cells to migrate to pre-selected organs in 
order to establish a hospitable environment. This event preceded the appearance of cancer cells by four to six days and micrometastatic colonies formed five days later [11]. These studies might explain the unpredictable metastatic pattern of renal tumors and account for the late appearance of metastatic disease in organs and sites that are considered outside of the "usual" metastatic pathway of RCC.

\section{Rare metastatic sites of renal cell cancer}

A Medline/PubMed search for articles in English (mostly case series and case reports) on rare metastatic sites of renal carcinomas was performed. In our search we considered as rare all sites that were anatomically distal to the kidney and outside the considered usual chain of metastatic spread of renal tumors. For that reason we excluded all sites of common metastases from renal tumors, including the lungs, adrenals, intestines and brain and most intra-abdominal organs, and only included rare metastatic sites outside the abdomen.

\section{Head and neck}

RCC is the third most frequent neoplasm to metastasize to the head and neck region preceded only by breast and lung cancer. Despite being reported infrequently, head and neck region metastases may be linked to RCC in up to $15 \%$ of cases [12]. The nose and paranasal sinuses are most commonly affected, followed by the oral cavity.

\section{Orbit}

Ocular metastases from RCCs are extremely rare. During the last five years only 19 cases have been reported. Ocular metastases are more likely to involve the iris, ciliary body and choroids, although eyelid, lacrimal sac and orbital metastases have also been described [13-16]. Among those 19 cases, 13 involved men and only three involved women. In three cases there was no mention of the gender. The mean age at initial diagnosis was 50 years. In seven cases the eye or orbital metastasis was the first manifestation of a previously unknown RCC, while in 10 cases there was a history of nephrectomy for RCC (one month to 17 years before the diagnosis of the ocular metastatic lesion). In two cases there was no mention of the previous medical history. The patients presented with several symptoms depending on the localization of the tumor, such as proptosis, diplopia, eye vision difficulties, cataract, upper lid tumor, and epiphora. The final diagnosis occurred after excision biopsy which revealed metastatic RCC. In Table 1 all cases with metastases to the orbit are presented in detail.

\section{Parotid gland}

Major salivary gland metastases from distant primary tumors are very uncommon. Parotid metastatic lesions may originate from hepatocellular carcinoma, squamous cell carcinoma, melanoma, retinoblastoma, carcinoma of the breast, urachus, prostate, stomach, lungs or kidneys. An extensive literature search revealed a total of 26 cases of RCC metastatic to the parotid gland. In 14 of these patients, parotid metastasis was the initial sign of the kidney tumor. In the other 12 cases, parotid metastasis occurred after nephrectomy for RCC, at a time interval ranging from months to years [17-22].

To the best of our knowledge, the longest interval from nephrectomy to solitary parotid metastasis was 10 years. The most common presenting symptom was the presence of a palpable parotid mass, while in one case facial paralysis was the presenting symptom. In all cases fine-needle aspiration (FNA) biopsy was diagnostic. Some cases are presented in detail in Table 2[17-26].

With regard to solitary submaxillary gland metastasis from RCC, we were able to retrieve three cases. These involved an 83-year-old man where metastatic tumor presented 10 years after primary treatment; a 52- yearold woman with a growing mass at the base of her tongue (minor salivary gland) and no known history of renal cancer and a 61-year-old patient who presented seven years after primary treatment, with metastasis to both the submandibular glands and the thyroid $[26,27]$.

\section{Nasal and paranasal cavities}

The nose is another very uncommon site for metastatic RCC. Approximately 50 cases of nasal recurrences of RCC have been reported in the literature. The maxillary sinuses are the paranasal sinuses most commonly afflicted by metastatic tumors to the sinonasal region, followed in frequency by the ethmoid, frontal, and sphenoid, while there is only one reported case of an isolated metastasis to the nasal septum.

Tumor involvement of the paranasal sinuses and nasal fossae appears to occur via the hematogenous route through the Batson's paravertebral venous plexus. This is an anastomotic network of avalvular veins surrounding the bone marrow and vertebras, connected with pelvic, intercostal, azygos and cava veins, therefore allowing tumor seeding in both a caudal direction toward the pelvis and a cranial direction to the calotte. Increased intra-abdominal or intrathoracic pressure causes an increased flow to the paravertebral plexus, from which venous sinuses in the calotte, and retrogradely the pterygoid plexus, are reached before arriving at the paranasal sinuses. This theory explains how tumor cells may escape the pulmonary capillary filter and how renal, pulmonary, genitourinary, or breast tumors can metastasize into the paranasal sinuses [28].

The most frequent patients' complaints were nasal obstruction, swelling and pain, although epistaxis is the most alarming symptom because of the high vascular 
Table 1 Cases of RCC metastases to the orbit

\begin{tabular}{|c|c|c|c|c|c|c|}
\hline $\begin{array}{l}\text { Patient sex } \\
\text { age at } \\
\text { diagnosis }\end{array}$ & Location & $\begin{array}{l}\text { Treatment of } \\
\text { primary } \\
\text { tumor }\end{array}$ & $\begin{array}{l}\text { Interval between diagnosis of } \\
\text { primary tumor and metastasis } \\
\text { (months) }\end{array}$ & $\begin{array}{l}\text { Diagnosis of metastasis } \\
\text { before primary } \\
\text { treatment }\end{array}$ & $\begin{array}{l}\text { Presenting } \\
\text { symptoms }\end{array}$ & $\begin{array}{l}\text { Metastases } \\
\text { to other sites }\end{array}$ \\
\hline $\mathrm{m} / 54$ & Uvea & Nephrectomy & 36 & no & $\begin{array}{l}\text { Eye vision } \\
\text { problem }\end{array}$ & - \\
\hline NA & $\begin{array}{l}\text { Bilateral lacrimal } \\
\text { gland }\end{array}$ & NA & NA & NA & NA & - \\
\hline $\mathrm{m} / 43$ & $\begin{array}{l}\text { Choroidal and } \\
\text { conjunctival }\end{array}$ & Nephrectomy & 12 & no & $\begin{array}{l}\text { Left orbital } \\
\text { pain }\end{array}$ & - \\
\hline NA & $\begin{array}{l}\text { Choroidal, ocular, } \\
\text { extraocular, } \\
\text { vitreous }\end{array}$ & Nephrectomy & 96 & no & Cataract & - \\
\hline $\mathrm{m} / 52$ & Choroidal & Nephrectomy & 24 & no & $\begin{array}{l}\text { Eye vision } \\
\text { problem }\end{array}$ & Lung \\
\hline $\mathrm{m} / 63$ & Eyelid & $\begin{array}{l}\text { Nephrectomy/ } \\
\text { chemotherapy }\end{array}$ & NA & no & $\begin{array}{l}\text { Upper lid } \\
\text { tumor }\end{array}$ & Lung \\
\hline $\mathrm{m} / 58$ & $\begin{array}{l}\text { Inferior rectus } \\
\text { muscle }\end{array}$ & - & Metastasis first & yes & $\begin{array}{l}\text { Proptosis } \\
\text { and } \\
\text { diplopia }\end{array}$ & - \\
\hline f/NA & Lacrimal sac & Nephrectomy & NA & NA & Epiphora & - \\
\hline $\mathrm{m} / 73$ & Orbit & Nephrectomy & 204 & no & Epistaxis & $\begin{array}{l}\text { Nasal cavity, } \\
\text { ethmoidal } \\
\text { sinus }\end{array}$ \\
\hline $\mathrm{m} / 67$ & Iris & Nephrectomy & NA & no & NA & - \\
\hline $\mathrm{m} / 58$ & Orbit & - & Metastasis first & yes & NA & - \\
\hline$f / 23$ & Orbit & Nephrectomy & one & no & NA & - \\
\hline$f / 60$ & Orbit & - & Metastasis first & yes & Proptosis & - \\
\hline $\mathrm{m} / 69$ & Orbit & - & Metastasis first & yes & Proptosis & - \\
\hline $\mathrm{m} / 66$ & Eyelid & Nephrectomy & 15 & no & NA & $\begin{array}{l}\text { Lung, skin, } \\
\text { brain }\end{array}$ \\
\hline $\mathrm{m} / 47$ & Eyelid & Nephrectomy & 33 & no & NA & $\begin{array}{l}\text { Abdomen, } \\
\text { skin, lung }\end{array}$ \\
\hline $\mathrm{m} / 59$ & Retroocular & - & Metastasis first & yes & $\begin{array}{l}\text { Proptosis } \\
\text { and } \\
\text { diplopia }\end{array}$ & - \\
\hline $\mathrm{m} / 72$ & Conjuctival & - & Metastasis first & yes & $\begin{array}{l}\text { Ulcerated } \\
\text { lesion }\end{array}$ & - \\
\hline $\mathrm{m} / 70$ & Orbit & - & Metastasis first & yes & Cataract & - \\
\hline
\end{tabular}

f: female; m: male; NA: not available

stroma of these metastatic deposits. The high vasculature of RCC resulting in bleeding is probably caused by the fact that the von Hippel-Lindau gene mutation causes upregulation of hypoxia-induced factor $1 \alpha$, which in turn leads to angiogenesis through vascular endothelial growth factor upregulation. In cases of uncontrollable bleeding, immediate surgical removal is mandatory [29].

In 15 of these cases there was no known history of renal mass, while the rest of the patients had previously undergone nephrectomy at a time interval ranging from eight to 18 years prior to the diagnosis of the metastatic lesion to the nasal or paranasal cavities. In the majority of the cases there were also synchronous metastases to other parts of the body like small intestine, lungs and thyroid glands. The definitive diagnosis (Table 3) was based on pathology of the lesion, supplemented by imaging studies (computed tomography and magnetic resonance imaging (MRI)) [30-33].

\section{Tongue and tonsils}

The tongue is a frequent target for RCC metastasis although isolated spread to the floor of the mouth is rare. Lesions in the tongue or floor of the mouth can cause severe pain, bleeding, difficulty eating and even complete oral obstruction. Unfortunately, oral cavity metastasis from RCC is usually a manifestation of widespread disease [34]. The literature review revealed 28 cases of RCC metastatic to the tongue. Out of these, only five cases presented initially with tongue metastases before the primary diagnosis of RCC [35,36]. 
Table 2 Cases of RCC metastases to the salivary glands

\begin{tabular}{|c|c|c|c|c|c|}
\hline $\begin{array}{l}\text { Patient sex and } \\
\text { age at diagnosis }\end{array}$ & Location & $\begin{array}{l}\text { Treatment of } \\
\text { primary tumor }\end{array}$ & $\begin{array}{l}\text { Interval between diagnosis of primary } \\
\text { tumor and metastasis (months) }\end{array}$ & $\begin{array}{l}\text { Diagnosis of metastasis } \\
\text { before primary treatment }\end{array}$ & $\begin{array}{l}\text { Presenting } \\
\text { symptoms }\end{array}$ \\
\hline NA & parotid gland & NA & NA & NA & facial nerve palsy \\
\hline$f / 58$ & parotid gland & - & Metastasis first & yes & painless mass \\
\hline$f / 76$ & parotid gland & Nephrectomy & 108 & no & painless mass \\
\hline$f / 62$ & parotid gland & Nephrectomy & 60 & no & painless mass \\
\hline NA & parotid gland & NA & NA & NA & painless mass \\
\hline NA & parotid gland & NA & NA & NA & painless mass \\
\hline NA & parotid gland & Nephrectomy & NA & no & painless mass \\
\hline NA & parotid gland & Nephrectomy & 120 & no & painless mass \\
\hline NA & parotid gland & Nephrectomy & 24 & NA & painless mass \\
\hline $\mathrm{m} / 66$ & parotid gland & Nephrectomy & 18 & NA & painless mass \\
\hline $\mathrm{m} / 69$ & parotid gland & Nephrectomy & 24 & no & painless mass \\
\hline$f / 59$ & parotid gland & Nephrectomy & 120 & no & painless mass \\
\hline$f / 61$ & parotid gland & - & Metastasis first & yes & painless mass \\
\hline $\mathrm{m} / 83$ & $\begin{array}{l}\text { submaxillary } \\
\text { gland }\end{array}$ & Nephrectomy & 120 & no & NA \\
\hline$f / 52$ & $\begin{array}{l}\text { minor salivary } \\
\text { gland }\end{array}$ & - & Metastasis first & yes & NA \\
\hline$f / 61$ & $\begin{array}{l}\text { submandibular } \\
\text { glands }\end{array}$ & Nephrectomy & 84 & no & $\begin{array}{l}\text { Painless } \\
\text { submandibular } \\
\text { swelling }\end{array}$ \\
\hline
\end{tabular}

f: female; m: male; NA: not available

As in most cases with distal metastases, prognosis for patients with lingual metastasis from RCC is poor. Treatment of tongue metastasis is usually palliative and aims to provide patient comfort by means of pain relief while preventing bleeding, infection and breathing difficulties. Surgical excision is recommended as palliative treatment with emphasis on preservation of tongue structure and function [34-42].

Table 3 RCC metastases to the nasal and paranasal regions

\begin{tabular}{|c|c|c|c|c|c|c|}
\hline $\begin{array}{l}\text { Sex/age at } \\
\text { diagnosis }\end{array}$ & Location & $\begin{array}{l}\text { Treatment of } \\
\text { primary tumor }\end{array}$ & $\begin{array}{l}\text { Interval between diagnosis of } \\
\text { primary tumor and metastasis }\end{array}$ & $\begin{array}{l}\text { Diagnosis of metastasis } \\
\text { before primary treatment }\end{array}$ & $\begin{array}{l}\text { Presenting } \\
\text { symptoms }\end{array}$ & $\begin{array}{l}\text { Metastases to } \\
\text { other sites }\end{array}$ \\
\hline$f / 65$ & Nasal & Nephrectomy & 17 years & no & epistaxis & $\begin{array}{l}\text { Thyroid, small } \\
\text { intestine }\end{array}$ \\
\hline $\mathrm{m} / 58$ & $\begin{array}{l}\text { Maxillary } \\
\text { Sinus }\end{array}$ & Nephrectomy & 11 years & no & $\begin{array}{l}\text { lasting nasal } \\
\text { obstruction }\end{array}$ & Lung \\
\hline$f / 69$ & Nasal & Nephrectomy & NA & no & NA & Lung \\
\hline$f / 60$ & $\begin{array}{l}\text { Maxillary } \\
\text { Sinus }\end{array}$ & Nephrectomy & 10 years & no & $\begin{array}{l}\text { Hyposmia, } \\
\text { pain }\end{array}$ & - \\
\hline$f / 87$ & $\begin{array}{l}\text { Maxillary } \\
\text { Sinus }\end{array}$ & Nephrectomy & eight years & no & $\begin{array}{l}\text { epistaxis, nasal } \\
\text { obstruction }\end{array}$ & - \\
\hline $\mathrm{m} / 71$ & Nasal & Nephrectomy & NA & no & $\begin{array}{l}\text { epistaxis, nasal } \\
\text { obstruction }\end{array}$ & Lung \\
\hline N.A & Nose & - & Metastasis first & yes & NA & - \\
\hline $\mathrm{m} / 73$ & $\begin{array}{l}\text { Ethmoid } \\
\text { sinus }\end{array}$ & - & Metastasis first & yes & epistaxis & - \\
\hline N.A & $\begin{array}{l}\text { Ethmoid } \\
\text { sinus }\end{array}$ & Nephrectomy & 17 years & NA & $\begin{array}{l}\text { epistaxis, nasal } \\
\text { obstruction }\end{array}$ & - \\
\hline$f / 45$ & $\begin{array}{l}\text { Nasal } \\
\text { Septum }\end{array}$ & - & NA & NA & NA & - \\
\hline $\mathrm{m} / 70$ & Nasosinusal & - & Metastasis first & yes & epistaxis & - \\
\hline $\mathrm{m} / 60$ & $\begin{array}{l}\text { Maxillary } \\
\text { Sinus }\end{array}$ & Nephrectomy & six months & NA & NA & - \\
\hline
\end{tabular}


To the best of our knowledge only two cases of tonsil metastases from RCC have been reported during the last five years. Both patients were men, 61- and 76years-old respectively, with known history of RCC and previously diagnosed bone and lung metastases [41,42].

\section{Thyroid gland}

Although secondary involvement of the thyroid gland by RCC is uncommon, more than 150 cases of clinically recognized metastatic RCC to the thyroid have been reported in the English literature. Metastatic disease from the kidney to the thyroid gland can occur more than 20 years after nephrectomy, with an average time interval of approximately seven and a half years. Among them we found only five cases where metastasis to the thyroid gland was the first manifestation of RCC [43-45]. Some cases are depicted in Table 4[43-48].

There are hypotheses explaining the relatively high incidence of metastases from the kidney to the thyroid gland. Although a popular theory claims that the proclivity of metastasis to the thyroid gland is related to its rich blood supply, some researchers have suggested that the abnormal thyroid gland is vulnerable to metastatic growth due to a decrease in oxygen and iodine content alteration [49].

Metastatic disease to the thyroid can manifest as breathing difficulties due to enlargement-swelling of the thyroid causing airway obstruction. Other symptoms include trouble or pain in swallowing, cough due to the vasogastric effect or a variety of symptoms of hypothyroidism [50]. Diagnosis is confirmed by thyroid scintigraphy, thyroid ultrasonography, and cytology of the material obtained through FNA [51].

\section{Heart}

Isolated metastasis of RCC to the left ventricle of the heart is considered a rare incident. Historically, up to $10 \%$ of patients with RCC have tumor thrombus involving the renal vein and inferior vena cava and in up to $1 \%$ tumor thrombus extends into the right atrium. Metastasis to the left ventricle as to any other organ is possible via the hematogenous route. There have been rare reports of solitary late metastasis to the heart with the right ventricle being the preferred chamber involved. Metastasis to the heart may have two distinct origins and clinical features. The first is hematogenous, via the inferior vena cava, even in the absence of renal vein involvement; it is generally circumscribed and has a good prognosis after surgery. The second is through the intrathoracic lymphatic system, in the presence of disseminated disease, especially pulmonary metastasis. This type has a very poor prognosis [52].

There have been 10 reports within the last five years of cardiac metastases from RCC. In one case, a malignant pericardial effusion was the sole evidence of metastatic disease and was treated by radiation therapy [53]. In three cases [53-55] right atrial metastasis occurred, one of which displayed the absence of a vena cava tumor extension [54]. In three cases left ventricular metastasis occurred 18 to 23 years after nephrectomy [56-58]. In two cases there was right ventricular metastasis from RCC, which was diagnosed incidentally after an episode of syncope in the first case [59] and during the evaluation of hematuria in the second one [60]. Finally one case involved metastasis to the interventricular septum which caused cardiac paradox [61]. In Table 5 those cases are presented in detail.

\section{Skin}

Skin metastases of RCC are not easily identified because of the low suspicion index for these skin lesions, which usually mimic common dermatological disorders. Moreover in the majority of cases the pathogenesis of the skin lesion is not related to the primary tumor due to the long time interval since nephrectomy. Skin metastases have been reported to occur in around 3\% of renal

Table 4 Cases of RCC metastases only to the thyroid gland

\begin{tabular}{|c|c|c|c|c|}
\hline $\begin{array}{l}\text { Sex/age at } \\
\text { diagnosis }\end{array}$ & $\begin{array}{l}\text { Treatment of primary } \\
\text { tumor }\end{array}$ & $\begin{array}{l}\text { Interval Between Diagnosis of primary tumor } \\
\text { and metastases }\end{array}$ & $\begin{array}{l}\text { Diagnosis of Metastasis } \\
\text { before PT }\end{array}$ & Symptom \\
\hline $\mathrm{m} / 54$ & - & Metastasis first & yes & Dysphagia \\
\hline $\mathrm{m} / 73$ & Nephrectomy & eight years & NA & $\begin{array}{l}\text { Painful mass, } \\
\text { dyspnoea }\end{array}$ \\
\hline$f / 61$ & Nephrectomy & seven years & no & N.A \\
\hline$m / 72$ & Nephrectomy & 17 years & no & swelling \\
\hline$f / 66$ & Nephrectomy & 16 years & no & N.A \\
\hline$m / 61$ & Nephrectomy & eight years & no & swelling, cough \\
\hline $\mathrm{m} / 68$ & Nephrectomy & two years & no & asymptomatic \\
\hline $\begin{array}{l}4 \mathrm{~m} / 60-83,6 f / 56- \\
83\end{array}$ & $\begin{array}{l}\text { Nephrectomy in six } \\
\text { cases }\end{array}$ & & yes in four cases & \\
\hline
\end{tabular}

f: female; m: male; NA: not available 
Table 5 Cases with RCC metastasis to the heart, N

\begin{tabular}{|c|c|c|c|c|c|c|}
\hline $\begin{array}{l}\text { Sex/age at } \\
\text { diagnosis }\end{array}$ & Location & $\begin{array}{l}\text { Treatment of } \\
\text { primary tumor }\end{array}$ & $\begin{array}{l}\text { Interval between diagnosis of } \\
\text { primary tumor and metastasis }\end{array}$ & $\begin{array}{l}\text { Diagnosis of metastasis } \\
\text { before primary treatment }\end{array}$ & $\begin{array}{l}\text { Presenting } \\
\text { symptoms }\end{array}$ & $\begin{array}{l}\text { IVC } \\
\text { involvement }\end{array}$ \\
\hline$f / 67$ & $\begin{array}{l}\text { Interverticular } \\
\text { septum }\end{array}$ & Nephrectomy & three months & no & Dyspnea & N.A \\
\hline $\mathrm{m} / 50$ & Right atrium & Nephrectomy & six years & no & $\begin{array}{l}\text { Budd-Chiari } \\
\text { Syndrome }\end{array}$ & Yes \\
\hline $\mathrm{m} / 59$ & $\begin{array}{l}\text { Right } \\
\text { ventricle }\end{array}$ & - & Metastasis first & yes & Syncope & No \\
\hline $\mathrm{m} / 59$ & $\begin{array}{l}\text { Pericardial, } \\
\text { myocardial }\end{array}$ & Nephrectomy & NA & no & Cardiac arrest & No \\
\hline $\mathrm{m} / 69$ & Left ventricle & Nephrectomy & 23 years & no & NA & NA \\
\hline $\mathrm{m} / 65$ & Left ventricle & Nephrectomy & 20 years & no & NA & NA \\
\hline $\mathrm{m} / 50$ & Right atrium & Nephrectomy & one year & No & $\begin{array}{l}\text { Raynaud-like } \\
\text { phenomena, } \\
\text { fatigue }\end{array}$ & No \\
\hline$f / 59$ & Right atrium & - & zero & synchronous & NA & Yes \\
\hline $\mathrm{m} / 69$ & Left ventricle & Nephrectomy & 18 years & No & $\begin{array}{l}\text { Shortness of } \\
\text { breath }\end{array}$ & No \\
\hline $\mathrm{m} / 55$ & $\begin{array}{l}\text { Right } \\
\text { ventricle }\end{array}$ & - & zero & synchronous & Hematuria & No \\
\hline
\end{tabular}

f: female; m: male; NA: not available

tumors. They are more common in males. Several cases of calvarial metastases as secondary lesions from RCC have been reported in the literature, but only five cases have been described concerning calvarial mass as the first clinical presentation of metastatic RCC [62-64].

Skin metastases mainly occur in the head, neck and trunk, in that order. Skin metastases from RCC occur in most patients at a late stage of the disease, usually years after nephrectomy for an organ-confined tumor. However in some cases they may occur even before the renal tumor is diagnosed [65]. Skin metastases are usually considered late manifestations of the disease, bearing a poor prognosis that is associated to synchronous visceral metastases in up to $90 \%$ of cases, resulting in tumorspecific survival of usually shorter than six months [66-73].

\section{Ovaries-Uterus-Testis}

Metastasis to the ovaries is thought to occur by retrograde venous embolization through the renal vein to the ovarian vessels. In an autopsy study, ovarian metastasis was found in $0.5 \%$ of cases of renal cancer. Metastasis through this pathway exploits the unique anatomy of the left renal and ovarian veins. It mandates incompetent gonadal veins to allow for retrograde venous blood flow. As a matter of fact, two thirds of reported cases arose from a left-sided lesion. Thus, it appears that the hallmark for the renal-ovarian axis is its unique venous anatomy. Only 21 cases of metastasis to the ovary from RCC have been reported in the literature (eight cases in the last five years). Out of these, 17 cases were metastasis of RCC of clear cell type. Six of these cases were diagnosed as primary ovarian clear cell cancer, while renal primary was diagnosed only after extensive investigations [74-81].

Regarding the vagina and uterus, to our knowledge, there is one report in the literature of metastatic oncocytic papillary RCC to the endometrium in an 89-yearold woman presented with vaginal bleeding, one of vaginal metastasis from RCC and another one of cervical carcinoma in a 45 -year-old woman $[80,81]$.

With regard to metastatic testicular involvement, the incidence of secondary testicular tumors ranges from $0.3 \%$ to $3.6 \%$ with the most frequent primary site being the prostate [82]. Intrascrotal metastasis arising from RCC has also been reported [83]. The pathologic diagnosis of RCC metastatic to the testis almost always reveals a clear cell tumor pathology [84]. To our knowledge only six cases of testicular metastases from RCC have been reported within the last five years, in one of the six, there was a contralateral chromophobe RCC metastatic to the testis, six years after nephrectomy $[85,86]$.

\section{Muscle and joints}

RCC metastatic to muscles is a very rare incident indeed. According to Satake et al., up until 2009 only 32 cases of skeletal muscle metastasis from RCC had been reported; our search added another three. The fact is that there are very few cases with muscle metastasis from RCC with each metastatic location comprising a unique case report $[87,88]$. 
Only three cases of acute monarthritis secondary to asymptomatic RCC have been described. The patients were initially diagnosed with septic arthritis. However the finding of hot spots on isotope bone scans and biopsy samples showing secondary neoplasms confirmed the lesions to represent metastatic sites of RCCs. MRI has been proven helpful in delineating the features and extent of the muscle invasion by the tumor $[88,89]$.

\section{Conclusions}

RCC represents a potentially lethal cancer that is associated with aggressive behavior and has a propensity for metastatic spread. The patterns of metastases from RCCs are not yet defined with accuracy and, as a result, RCC has been associated with rare metastatic sites and occasionally atypical presenting symptoms from disseminated disease and distant metastatic sites.

The present review has focused on these rare incidences of metastatic spread of RCC to uncommon sites and organs both at the time of diagnosis of the primary tumor but also years after radical nephrectomy. This review is mainly based on published case reports relevant to the metastatic potential of RCC. This fact further highlights the significance of case reporting, especially in oncology where clinical trials or even large case series are not always available, as Dib et al. have very elegantly pointed out [90]. The contribution of case reporting should not be underestimated since many of our classical clinical teachings have originated from the observation of isolated "case reports".

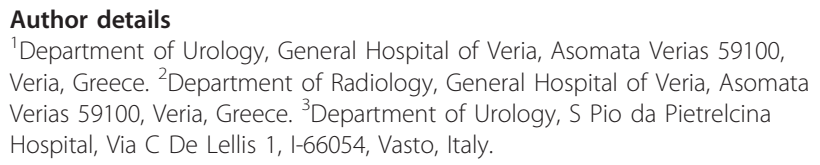

\section{Authors' contributions}

PS and LC were responsible for the concept of the article and reviewed the final draft, LM reviewed the relevant papers and wrote the first draft of the paper. All authors have read and approved the final manuscript.

\section{Competing interests}

The authors declare that they have no competing interests.

Received: 17 December 2010 Accepted: 2 September 2011

Published: 2 September 2011

\section{References}

1. Jemal A, Siegel R, Ward E, Murray T, Xu J, Smigal C, Thun MJ: Cancer statistics 2006. CA Cancer J Clin 2006, 56(2):106-130.

2. Chen DY, Uzzo RG: Evaluation and management of the renal mass. Med Clin North Am 2011, 95(1):179-189.

3. Hudes GR, Berkenblit A, Feingold J, Atkins MB, Rini BI, Dutcher J: Clinical trial experience with temsirolimus in patients with advanced renal cell carcinoma. Semin Oncol 2009, 36(Suppl 3):S26-36.

4. Hudes G, Carducci M, Tomczak P, Dutcher J, Figlin R, Kapoor A, Staroslawska E, Sosman J, McDermott D, Bodrogi I, Kovacevic Z, Lesovoy V, Schmidt-Wolf IG, Barbarash O, Gokmen E, O'Toole T, Lustgarten S, Moore L,
Motzer RJ, Global ARCC Trial: Temsirolimus, interferon alfa, or both for advanced renal-cell carcinoma. N Engl J Med 2007, 356(22):2271-2281.

5. Mekhail TM, Abou-Jawde RM, Boumerhi G Malhi S, Wood L, Elson P, Bukowski R: Validation and extension of the Memorial Sloan Kettering prognostic factors model for survival in patients with previously untreated renal metastatic renal cell carcinoma. J Clin Oncol 2005, 23(4):832-841.

6. Crotty TB, Farrow GM, Lieber MM: Chromophobe cell renal carcinoma: clinicopathological features of 50 cases. J Urol 1995, 154(3):964-967.

7. Thoenes W, Storkel S, Rumpelt HJ, Moll R, Baum HP, Werner S: Chromophobe cell renal carcinoma and its variants-a report on 32 cases. J Pathol 1988, 155(4):277-287.

8. Kontak JA, Campbell SC: Prognostic factors in renal cell carcinoma. Urol Clin North Am 2003, 30(3):467-480.

9. Oppenheimer SB: Cellular basis of cancer metastasis: A review of fundamentals and new advances. Acta Histochemica 2006, 108(5):327-334.

10. Podsypanina K, Du YC, Jechlinger M, Beverly LJ, Hambardzumyan D, Varmus $\mathrm{H}$ : Seeding and propagation of untransformed mouse mammary cells in the lung. Science 2008, 321(5897):1841-1844.

11. Kaplan RN, Riba RD, Zacharoulis S, Bramley AH, Vincent L, Costa C, MacDonald DD, Jin DK, Shido K, Kerns SA, Zhu Z, Hicklin D, Wu Y, Port JL, Altorki N, Port ER, Ruggero D, Shmelkov SV, Jensen KK, Rafii S, Lyden D: VEGFR-1 positive haematopoietic bone marrow progenitors initiate the pre-metastatic niche. Nature 2005, 438(7069):820-827.

12. Pritchyk KM, Schiff BA, Newkirk KA, Krowiak E, Deeb ZE: Metastatic renal cell carcinoma to the head and neck. Laryngoscope 2002, 112:1598-1601.

13. Sabatini P, Ducic Y: Bilateral lacrimal gland masses: unusual case of metastatic renal cell carcinoma. J Otolaryngol Head Neck Surg 2009, 38(1): E1-2.

14. Rodney AJ, Gombos DS, Fuller GN, Pagliaro LC, Tannir NM: Choroidal and conjunctival metastases from renal cell carcinoma. Am J Clin Oncol 2009, 32(4):448-449.

15. Shoaib KK, Haq IU, Ali K, Mukhtar MA, Nazir M: Choroidal metastasis from renal cell carcinoma presenting with cataract. J Coll Physicians Surg Pak 2008, 18(6):380-381.

16. Kurli M, Finger PT, Schneider S, Tena LB: Eyelid-sparing adjuvant radiation therapy for renal cell carcinoma. Ophthalmologica 2006, 220(3):198-200.

17. Seijas BP, Franco FL, Sastre RM, García AA, López-Cedrún Cembranos JL: Metastatic renal cell carcinoma presenting as a parotid tumor. Oral Surg Oral Med Oral Pathol Oral Radiol Endod 2005, 99(5):554-557.

18. Spreafico R, Nicoletti G, Ferrario F, Scanziani R, Grasso M: Parotid metastasis from renal cell carcinoma: a case report and review of the literature. ACTA Otorhinolaryngologica Italica 2008, 28(5):266-268.

19. Dequanter D, Lothaire P, Andry AG: Secondary malignant tumors of the parotid. Otolaryngol Chir Cervicofac 2005, 122(1):18-20.

20. Kundu S, Eynon-Lewis NJ, Radcliffe GJ: Extensive metastatic renal cell carcinoma presenting as facial nerve palsy. J Laryngol Otol 2001, 115(6):488-490.

21. Gonçalves $A C$, Costa $P G$, Monteiro ML: Inferior rectus muscle metastasis as a presenting sign of renal cell carcinoma:case report. Ara Bras Oftalmol 2006, 69(3):435-438.

22. Mrena R, Leivo I, Passador-Santos F, Hagström J, Mäkitie AA: Histopathological findings in parotid gland metastases from renal cell carcinoma. Eur Arch Otorhinolaryngol 2008, 265(9):1005-1009.

23. Pomar Blanco P, Martín Villares C, San Román Carbajo J, Tapia Risueño M, Fernández Pello M: Metastasis to the parotid gland. Acta Otorrinolaringol Esp 2006, 57(1):47-50.

24. Andreadis D, Nomikos A, Barbatis C: Metastatic renal clear cell carcinoma in the parotid gland: a study of immunohistochemical profile and cell adhesion molecules (CAMs) expression in two cases. Pathol Oncol Res 2007, 13(2):161-165.

25. Spreafico R, Nicoletti G, Ferrario F, Scanziani R, Grasso M: Parotid metastasis from renal cell carcinoma:a case report and review of the literature. ACTA Otorhinolaryngol Ital 2008, 28(5):266-268.

26. Moudouni SM, Tligui M, Doublet JD, Haab F, Gattegno B, Thibault P: Late metastasis of renal cell carcinoma to the submaxillary gland 10 years after radical nephrectomy. Int I Urol 2006, 13(4):431-432.

27. Lai G, Nemolato S, Lecca S, Parodo G, Medda C, Faa G: The role of immunohistochemistry in the diagnosis of hyalinizing clear cell carcinoma of the minor salivary gland: a case report. Eur J Histochem 2008, 52(4):251-254. 
28. Torres Muros B, Solano Romero JR, Rodríguez Baró JG, Bonilla Parrilla R: Maxillary sinus metastasis of renal cell carcinoma. Actas Urol Esp 2006, 30(9):954-957.

29. Lee HM, Kang HJ, Lee SH: Metastatic renal cell carcinoma presenting as epistaxis. Eur Arch Otorhinolaryngol 2005, 262(1):69-71.

30. Brener ZZ, Zhuravenko I, Jacob CE, Bergman M: An unusual presentation of renal cell carcinoma with late metastases to the small intestine, thyroid gland, nose and skull base. Nephrol Dial Transplant 2007, 22(3):930-932.

31. Sawazaki H, Segawa T, Yoshida K, Kawahara T, Inoue T, Soda T, Kanba T, Yoshimura K, Takahashi T, Nakamura E, Nishiyama H, Ito N, Kamoto T, Ogawa O: Bilateral maxillary sinus metastasis of renal cell carcinoma: a case report. Hinyokika Kiyo 2007, 53(4):231-234.

32. Kamiński B, Kobiorska-Nowak J, Bień S: Distant metastases to nasal cavities and paranasal sinuses, from the organs outside the head and neck. Otolaryngol Pol 2008, 62(4):422-425.

33. Duque-Fisher CS, Casiano R, Vélez-Hoyos A, Londoño-Bustamented AF: Metastasis to the sinonasal region. Acta Otorrinolaringol Esp 2009, 60(6):428-431.

34. Yoshitomi I, Kawasaki G, Mizuno A, Nishikido M, Hayashi T, Fujita S, Ikeda T: Lingual metastasis as an initial presentation of renal cell carcinoma. Med Oncol 2010.

35. Azam F, Abubakerr M, Gollins S: Tongue metastasis as an initial presentation of renal cell carcinoma: a case report and literature review. J Med Case Reports 2008, 2:249.

36. Cochrane TJ, Cheng L, Crean S: Renal cell carcinoma: A rare metastasis to the tongue-a case report. Dent Update 2006, 33(3):186-187.

37. Ziari M, Shen S, Amato RJ, Teh BS: Metastatic renal cell carcinoma to the nose and ethmoid sinus. Urology 2006, 67(1):199.

38. Basely M, Bonnel S, Maszelin P, Verdalle P, Bussy E, de Jaureguiberry JP: A rare presentation of metastatic renal clear cell carcinoma to the tongue seen on FDG PET. Clin Nucl Med 2009, 34(9):566-569.

39. Torres-Carranza E, Garcia-Perla A, Infante-Cossio P, Belmonte-Caro R, Loizaga-Iriondo JM, Gutierrez-Perez JL: Airway obstruction due to metastatic renal cell carcinoma to the tongue. Oral Surg Oral Med Oral Pathol Oral Radiol Endod 2006, 101(3):e76-78.

40. Stańczyk R, Omulecka A, Pajor A: A case of renal clear cell carcinoma metastasis to the oropharynx. Otolaryngol Pol 2006, 60(1):97-100.

41. Massaccesi M, Morganti AG, Serafini G, Di Lallo A, Deodato F, Picardi V, Scambia G: Late tonsil metastases from renal cell cancer: a case report. Tumori 2009, 95(4):521-524.

42. Miah MS, White SJ, Oommen G, Birney E, Majumdar S: Late simultaneous metastasis of renal cell carcinoma to the submandibular and thyroid glands seven years after radical nephrectomy. Int J Otolaryngol 2010.

43. Bugalho MJ, Mendonça E, Costa P, Santos JR, Silva E, Catarino AL, Sobrinho LG: A multinodular goiter as the initial presentation of a renal cell carcinoma harbouring a novel VHL mutation. BMC Endocrine Disorders 2006, 6:6.

44. Nixon Jl, Whitcher M, Glick J, Palmer LF, Shaha RA, Shah PJ, Patel GS, Ganly I: Surgical management of metastases to the thyroid gland. Ann Surg Oncol 2011, 18(3):800-804.

45. Lee WM, Batoroev KY, Odashiro NA, Nguyen G: Solitary metastatic cancer to the thyroid: a report of five cases with fine-needle aspiration cytology. Cyto Journal 2007, 4:5.

46. Dionigi G, Uccella S, Gandolfo M, Lai A, Bertocchi V, Rovera F, Tanda ML: Solitary intrathyroidal metastasis of renal clear cell carcinoma in a toxic substernal multinodular goiter. Thyroid Res 2008, 1:6.

47. Duggal NM, Horattas MC: Metastatic renal cell carcinoma to the thyroid gland. Endocr Pract 2008, 14(8):1040-1046.

48. Bohn OL, de las Casas LE, Leon ME: Tumor-to-tumor metastasis: Renal cell carcinoma metastatic to papillary carcinoma of thyroid-report of a case and review of the literature. Head Neck Pathol 2009, 3(4):327-330.

49. Testini M, Lissidini G, Gurrado A, Lastilla G, lanora AS, Fiorella R: Acute airway failure secondary to thyroid metastasis from renal carcinoma. World J Surg Oncol 2008, 6:14.

50. Garfield DH, Hercbergs A, Davis PJ: Re: Hypothyroidism in patients with metastatic renal cell carcinoma treated with sunitinib. J Natl Cancer Inst 2007, 99(12):975-976, author reply 976-977.

51. Buła G, Waler J, Niemiec A, Koziołek H, Bichalski W, Gawrychowski J: Diagnosis of metastatic tumours to the thyroid gland by fine needle aspiration biopsy. Endokrynol Pol 2010, 61(5):427-429.
52. Zustovich F, Gottardo F, De Zorzi L, Cecchetto A, Dal Bianco M, Mauro E, Cartei G: Cardiac metastasis from renal cell carcinoma without inferior vena involvement: a review of the literature based on a case report. Two different patterns of spread? Clin Oncol 2008, 13(3):271-274.

53. Marangoni G, O'Sullivan A, Ali A, Faraj W, Heaton N: Budd-Chiari syndrome secondary to caval recurrence of renal cell carcinoma. Hepatobiliary Pancreat Dis Int 2010, 9(3):321-324.

54. Selçuk $P$, Ayhan E, Gökhan K: Massive right atrial metastasis from renal cell carcinoma without inferior vena cava involvement. Arch Turk Soc Cardiol 2009, 37(5):358-360.

55. Anis A, Maldjian P, Klapholz M, Saric M: Renal cell carcinoma with extension to the heart. Can J Cardio/ 2008, 24(11):860.

56. Talukdera MQ, Deoa SV, Maleszewskib JJ, Parka SJ, Talukder MQ: Late isolated metastasis of renal cell carcinoma in the left 5 ventricular myocardium. Interact Cardiovasc Thorac Surg 2010, 11(6):814-816.

57. Bradley MS, Bolling FS: Late renal cell carcinoma metastasis to the left ventricular outflow tract. Ann Thorac Surg 1995, 60(1):204-206.

58. Aburto J, Bruckner AB, Blackmon HS, Beyer AE, Reardon JM: Renal cell carcinoma metastatic to the left ventricle. Tex Heart Inst J 2009, 36(1):48-49.

59. Alghamdi A, Tam J: Cardiac metastasis from a renal cell carcinoma. Can J Cardiol 2006, 22(14):1231-1232.

60. Otahbachi M, Çevik C, Sutthiwan P: Right ventricle and tricuspid valve metastasis in a patient with renal cell. Anadolu Kardiyol Derg 2009, 9(4): E11-12.

61. Osman F, Geh Jl, Griffith MJ: An unusual cause of cardiac paradox. Eur J Echocardiogr 2007, 8(2):91-92

62. Gaetani P, Di leva A, Colombo P, Tancioni F, Aimar E, Debernardi A, Baena RR: Calvarial metastases as clinical presentation of renal cell carcinoma: report of two cases and review of the literature. Clin Neurol Neurosurg 2005, 107(4):329-333.

63. Cohen PR: Metastatic tumors to the nail unit: subungual metastases. Dermatol Surg 2001, 27(3):280-293.

64. Martínez-Rodríguez R, Rodríguez-Escovar F, Bujons Tur A, Maroto P, Palou J, Villavicencio $\mathrm{H}$ : Skin metastasis during follow-up of a clear cell renal carcinoma. Arch Esp Urol 2008, 61(1):80-82.

65. Porter AN, Anderson LH, Al-Dujaily S: Renal cell carcinoma presenting as a solitary cutaneous facial metastasis: case report and review of the literature. Int Semin Surg Oncol 2006, 3:27.

66. García Torrelles M, Beltrán Armada JR, Verges Prosper A, Santolaya García Jl, Espinosa Ruiz JJ, Tarín Planes M, Sanjuán de Laorden C: Skin metastases from a renal cell carcinoma. Actas Urol Esp 2007, 31(5):556-558.

67. Arrabal-Polo MA, Arias-Santiago SA, Aneiros-Fernandez J, Burkhardt-Perez $\mathrm{P}$, Arrabal-Martin M, Naranjo-Sintes R: Cutaneous metastases in renal cell carcinoma: a case report. Cases J 2009, 25(2):7948.

68. Jilani G, Mohamed D, Wadia H, Ramzi K, Meriem J, Houssem L, Samir G, Ben Nawfel R: Cutaneous metastasis of renal cell carcinoma through percutaneous fine needle aspiration biopsy: case report. Dermatol Online J 2010, 16(2):10.

69. Kouroupakis D, Patsea E, Sofras F, Apostolikas N: Renal cell carcinoma metastases to the skin: a not so rare case? Br J Urol 1995, 75(5):583-585.

70. Koga S, Tsuda S, Nishikido M, Matsuya F, Saito Y, Kanetake H: Renal cell carcinoma metastatic to the skin. Anticancer Res 2000, 20(3B):1939-1940.

71. Sarma DP, Wang JF, McAllister MV, Wang B, Shehan JM: Possible implantation carcinoma of the scalp following craniotomy for metastatic renal cell carcinoma. Dermatol Online J 2008, 14(6):20.

72. Onak Kandemir N, Barut F, YIlmaz K, Tokgoz H, Hosnuter M, Ozdamar SO: Renal cell carcinoma presenting with cutaneous metastasis: a case report. Case Report Med 2010.

73. Johnson RP, Krauland K, Owens NM, Peckham S: Renal medullary carcinoma metastatic to the scalp. Am J Dermatopathol 2011, 33(1):e11-13.

74. Kato $S$, Nishino $Y$, Ito $Y$, Takeuchi $T$, Ban $Y$, Uno H: Renal cell carcinoma metastatic to the ovary. Hinyokika Kiyo 2006, 52(11):859-862.

75. Toquero L, Aboumarzouk MO, Abbasi Z: Renal cell carcinoma metastasis to the ovary: a case report. Cases J 2009, 14(2):7472.

76. Albrizio M, La Fianza A, Gorone MS: Bilateral metachronous ovarian metastases from clear cell renal carcinoma: a case report. Cases J 2009, 5(2):7083.

77. Stolnicu S, Borda A, Radulescu D, Puscasiu L, Berger N, Nogales FF: Metastasis from papillary renal cell carcinoma masquerading as primary ovarian clear cell tumor. Pathol Res Pract 2007, 203(11):819-822. 
78. Jalón Monzón A, Alvarez Múgica M, Bulnes Vázquez V, González Alvarez RC, García Rodríguez J, Martín Benito JL, Ferrer Barriendo J, Regadera Sejas FJ: Ovarian metastasis of a primary renal cell carcinoma. Arch Esp Urol 2008, 61(4):534-537.

79. Tretheway D, Gebhardt JG, Dogra VS, Schiffhauer LM: Metastatic versus primary oncocytic papillary adenocarcinoma of the endometrium: a report of a case and review of the literature. Int I GynecolPathol 2009, 28(3):256-261.

80. Koike H, Okamoto T, Tanji S, Fujioka T, Kubo T, Ohhori T: Two cases of metastatic renal tumor. Hinyokika Kiyo 1989, 35(3):475-479.

81. Llarena Ibarguren R, García-Olaverri Rodríguez J, Azurmendi Arin I, Olano Grasa I, Pertusa Peña C: Metachronic testicular metastasis secondary to clear cell renal adenocarcinoma. Arch Esp Urol 2008, 61(4):531-533.

82. Schmorl P, Ostertag H, Conrad S: Intratesticular metastasis of renal cancer. Urologe A 2008, 47(8):1001-1003.

83. Steiner G, Heimbach D, Pakos E, Müller S: Simultaneous contralateral testicular metastasis from a renal clear cell carcinoma. Scand J Urol Nephrol 1999, 33(2):136-137.

84. Wu HY, Xu LW, Zhang YY, Yu YL, Li XD, Li GH: Metachronous contralateral testicular and bilateral adrenal metastasis of chromophobe renal cell carcinoma: a case report and review of the literature. J Zhejiang Univ SCi B 2010, 11(5):386-389.

85. Ulbright TM, Young RH: Metastatic carcinoma to the testis: a clinicopathologic analysis of 26 nonincidental cases with emphasis on deceptive features. Am J Surg Pathol 2008, 32(11):1683-1693.

86. Satake N, Ohno Y, Yoshioka K, Sakamoto N, Takeuchi H, Tachibana M: Case of renal cell carcinoma metastasized to iliopsoas muscle. Nippon Hinyokika Gakkai Zasshi 2009, 100(3):495-499.

87. Sakamoto A, Yoshida T, Matsuura S, Tanaka K, Matsuda S, Oda Y, Hori Y, Yokomizo A, Iwamoto Y: Metastasis to the gluteus maximus muscle from renal cell carcinoma with special emphasis on MRI features. World I Surg Oncol 2007, 4(5):88.

88. Picchio M, Mascetti C, Tanga I, Spaziani E: Metastasis from renal cell carcinoma presenting as skeletal muscle mass: a case report. Acta Chir Belg 2010, 110(3):399-401.

89. Hur J, Yoon CS, Jung WH: Multiple skeletal muscle metastases from renal cell carcinoma 19 years after radical nephrectomy. Acta Radiol 2007, 48(2):238-241.

90. Dib EG, Kidd MR, Saltman DC: Case reports and the fight against cancer. J Med Case Reports 2008, 2:39.

doi:10.1186/1752-1947-5-429

Cite this article as: Sountoulides et al:: Atypical presentations and rare metastatic sites of renal cell carcinoma: a review of case reports. Journal of Medical Case Reports 2011 5:429.

\section{Submit your next manuscript to BioMed Central and take full advantage of:}

- Convenient online submission

- Thorough peer review

- No space constraints or color figure charges

- Immediate publication on acceptance

- Inclusion in PubMed, CAS, Scopus and Google Scholar

- Research which is freely available for redistribution

Submit your manuscript at www.biomedcentral.com/submit
Biomed Central 